\title{
The effects of fish feeding by visitors on reef fish in a Marine Protected Area open to tourism
}

\author{
Yuri Cruz de Paula ${ }^{1 *}$ (), Alexandre Schiavetti ${ }^{2,5}$, Cláudio L. S. Sampaio ${ }^{3}$ \& Emiliano Calderon ${ }^{4,5}$ \\ ${ }^{1}$ Universidade Estadual de Santa Cruz, Programa de Pós-Graduação em Sistemas Aquáticos Tropicais, \\ Rodovia Jorge Amado, km 16, Bairro Salobrinho, Ilhéus, BA, Brasil \\ ${ }^{2}$ Universidade Estadual de Santa Cruz, Departamento de Ciências Agrárias e Ambientais, Rodovia Jorge \\ Amado, km 16, Bairro Salobrinho, Ilhéus, BA, Brasil \\ ${ }^{3}$ Universidade Federal de Alagoas, Unidade Educacional de Penedo, Laboratório de Ictiologia e Conservação, \\ Av. Beira Rio, s/n. Centro Histórico, Penedo, AL, Brasil \\ ${ }^{4}$ Universidade Federal do Rio de Janeiro, Programa de Pós-Graduação em Ciências Ambientais e \\ Conservação, Núcleo em Ecologia e Desenvolvimento Socioambiantal de Macaé, Av. São José do Barreto, 764, \\ São José do Barreto, Macaé, RJ, Brasil \\ ${ }^{5}$ Instituto Coral Vivo, Rua dos Coqueiros, 87, Santa Cruz Cabrália, BA, Brasil \\ *Corresponding author: Yuri Cruz de Paula, e-mail:yuri_c_p@hotmail.com
}

PAULA, Y. C., SCHIAVETTI, A., SAMPAIO, C. L. S., CALDERON, E. The effects of fish feeding by visitors on reef fish in a Marine Protected Area open to tourism. Biota Neotropica. 18(3): e20170339. http://dx.doi. org/10.1590/1676-0611-BN-2017-0339

\begin{abstract}
Coral reef-based tourism has risen sharply across the globe, coupled with an increase in fish feeding by visitors. Studies indicate that fish feeding is one of the leading causes of changes in distribution patterns, abundance, the structure of marine fish communities, and fish behavior. The aim of this study was to determine the effect of human presence and fish feeding on the behavior of reef fish by conducting in situ experiments in tide pools in a Marine Protected Area located at the northern limit of the Abrolhos Bank in the South Atlantic Ocean. Eight feeding sessions were conducted and filmed, resulting in a total of 160 minutes of video footage. Each filming session recorded four different experimental conditions alternating between human presence, human absence, and fish feeding. Our findings suggest that fish feeding may cause changes in fish behavior, such as habituation to human presence, conditioning to fish feeding, increased aggressiveness, attacks on humans, and short-term changes in species distribution. The continuation of fish feeding over time can cause an increase in the size of the populations of species that consume food provided during feeding and consequently trigger changes in the structure of communities.
\end{abstract}

Keywords: Abudefduf saxatilis, behavior, fish feeding, in situ experiment, South Atlantic, tide pools.

\section{O efeito da alimentação artificial em peixes recifais em uma Área Marinha Protegida com atividade turística}

Resumo: O uso turístico de recifes de corais tem aumentado fortemente em todo o mundo, e com ele o fornecimento de alimento aos peixes por humanos. Porém, estudos indicam essa atividade como causa de distúrbios nos padrões de distribuição, abundância, estrutura da comunidade e comportamento de peixes marinhos. O objetivo deste estudo foi determinar o efeito da presença humana e da alimentação artificial no comportamento dos peixes recifais, através de experimentos in situ realizados em piscinas de maré de uma Área Marinha Protegida no limite Norte do Banco dos Abrolhos, Atlântico Sul. Para isso foram realizadas 8 sessões (160 min) de filmagem remota do experimento de alimentação artificial. Cada sessão de filmagem registrou quatro tratamentos, os quais alternavam momentos de presença e ausência humana, e de alimentação dos peixes.Os resultados encontrados indicam que a alimentação artificial tem provocado alterações comportamentais nos peixes como a habituação à presença humana, condicionamento à oferta de alimento, aumento da agressividade, ataques a humanos e alterações na distribuição das espécies em curto prazo. A permanência da atividade de alimentação artificial, ao longo do tempo, pode provocar o aumento das populações que consomem o alimento oferecido e consequentemente, desencadear alterações na estrutura da comunidade.

Palavras-chave: Abudefduf saxatilis, alimentação de peixes, Atlântico Sul, comportamento, experimento in situ, piscinas de maré. 


\section{Introduction}

Coral reef ecosystems harbor rich biodiversity and are crucially important both from a socioeconomic and ecological standpoint, providing various environmental services and benefits, such as coastal protection, maintenance of fish stocks, ecotourism and species with pharmaceutical potential (Brander et al. 2007). However, coral reefs have been severely impacted by climate change (Mumby \& Anthony 2015), ocean acidification (Comeau et al. 2015), overfishing (McClanahan et al. 2015), sewage and industrial waste (Wear \& Thurber 2015), and tourism (Pereira et al. 2014).

Marine Protected Areas (MPAs) are areas set aside to protect marines ecosystems, including reef ecosystems, and play a critical role in conserving marine biodiversity and natural resources used by coastal populations (Giglio et al. 2015). The implementation of protective measures helps to keep reef communities healthy, thus maintaining their tourism attractiveness (Green \& Donnelly 2003) and contributing to the growth of tourism in these areas (Milazzo et al. 2002). However, studies demonstrate that poorly planned or intensive tourist use can adversely affect marine ecosystems and associated marine life (Creed \& AmadoFilho 1999, Eckrich \& Holmquist 2000, Albuquerque et al. 2014, Giglio et al. 2016). Several researchers have investigated the impacts of tourism on reef environments, including trampling (Sarmento \& Santos 2012, Giglio et al., 2017, Williamson et al. 2017), boat anchoring (Saphier \& Hoffmann 2005, Beeden et al. 2014, Kininmonth et al. 2014), free and autonomous diving (Lamb \& True 2014, Hein et al.2015), and fish feeding (Milazzo 2011, Feitosa et al. 2012, Bookhouse et al. 2013).

Fish feeding is a popular tourist attraction at coral reefs around the world (Giglio et al. 2015) and is used by tourism operators to lure specific species and give visitors an opportunity to observe marine life up close. However, research shows that this activity may disrupt distribution patterns, abundance and the structure of marine fish communities (Brunnschweiler \& Barnett 2013, Brunnschweiler et al. 2014), as well as affecting fish health by increasing fat deposition and vulnerability to diseases caused by microorganisms and ectoparasites (Semeniuk \& Rothley 2008).

One of the main impacts of this activity is changes in the natural behavior of fish. For example, by becoming used to the presence of humans, species that otherwise would not approach humans freely gather around bathers to seek supplementary feeding (Albuquerque et al. 2014). Furthermore, fish can also become dependent upon fish feeding (Ilarri et al. 2008) and, in the long term, the acquired behavior of obtaining food from human hands may reduce their ability to obtain food by themselves in the wild. Another behavioral change reported in the literature is increased aggressiveness during feeding, both in fish competing among themselves for food and towards the people who are feeding them (Milazzo 2011). Fish feeding may also lead to shifts in circadian rhythms, as observed in the naturally nocturnal southern stingray (Hypanus americanus), which has become diurnal due to daytime fish feeding activities (Corcoran et al. 2013).

Despite studies showing the negative impacts of artificial feeding, few MPAs have implemented fish feeding rules (Corcoran et al. 2013). There is also divergence of opinion among MPA managers in relation to fish feeding, given the trade-offs between financial sustainability and the negative impacts of the activity on the conservation of marine life (Hémery \& McClanahan 2005, Milazzo et al. 2005). In the Great
Barrier Reef Marine Park in Australia, for example, fish feeding is permitted provided that the total food used does not exceed $1 \mathrm{~kg}$ per day (GBRMPA 2000). In contrast, in the Booderee National Park, also in Australia, feeding marine life is prohibited. This divergence of opinion is also manifested in Kenya, where fish feeding is permitted in certain areas in the Malindi, Watamu, and Mombasa MPAs while being prohibited in the Kisite MPA. In Brazil, fish feeding was permitted in the Abrolhos Marine National Park up to 2003, when the activity was banned in the area.

Coral reef-based tourism has risen sharply across the globe (Milazzo et al. 2002), coupled with an increase in the amount of food fed to fish by visitors. Concerns over the negative impacts of fish feeding have led to an increase in studies assessing the effects of this activity on these unique ecosystems (Medeiros et al., 2007). However, only a few studies have assessed the impacts of fish feeding on coral reefs in the South Atlantic Ocean (Medeiros et al. 2007, Ilarri et al. 2008, Feitosa et al. 2012, Pereira et al. 2014, Albuquerque et al. 2014). Thus, detailed studies concentrating on this region are needed to gain a deeper understanding of the effects of fish feeding on the biology of reef fish, which range from physiological and behavioral aspects to impacts on fish communities, in order to improve the management and conservation of these areas.

The species belonging to the genus Abudefduf(Family: Pomacentridae) are omnivorous and may be considered generalists. This flexibility allows them to employ opportunistic feeding strategies, making them particularly susceptible to the effects of fish feeding. Studies have reported changes in behavior and the spatial distribution in three species $-A$. saxatilis (Medeiros et al. 2007, Ilarri et al. 2008, Feitosa et al. 2012, Albuquerque et al. 2014), A. sexfasciatus, and A. sparoides (Hémery \& McClanahan 2005). It is believed that these changes could have damaging long-term ecological and economic impacts.

In light of the above, the aim of this study was to determine the effect of human presence and fish feeding on the behavior of reef fish by conducting in situ experiments in a MPA northern limit of the Abrolhos Bank located in the South Atlantic.

\section{Material and Methods}

\section{Study area}

The Recife de Fora Marine Park (RFMP) is a MPA located at the northern limit of the Abrolhos Bank, approximately 4 kilometers from the coast and the city of Porto Seguro in the State of Bahia, Brazil. The park has an area of approximately $17.5 \mathrm{~km}^{2}$ and is located between parallels $16^{\circ} 23^{\circ e} 30^{\prime \prime} / 16^{\circ} 25^{\circ e} 06^{\prime \prime} \mathrm{S}$ and meridians $38^{\circ} 58^{\circ} 30^{\prime \prime} / 38^{\circ} 59^{\circ e} 18^{\prime \prime}$ W (Porto Seguro 2016) (Figure 1). The depth in the middle of the central plateau of the park varies from 6 to 8 meters in the internal portion to a maximum of 20 meters in its western portion (Costa Jr. et al. 2002). The RFMP is one of the region's main tourist attractions and received 50,000 visitors in 2015 .

The park harbors all 16 coral reef builder species described in Brazil (Castro \& Pires 2001) and 43 fish species have been recorded in the area to date (Chaves et al. 2010), including Gramma brasiliensis Sazima, Gasparini \& Moura 1998, Sparisoma amplum (Ranzani 1841), Elacatinus figaro Sazima, Moura \& Rosa 1997, and Scarus trispinosus 


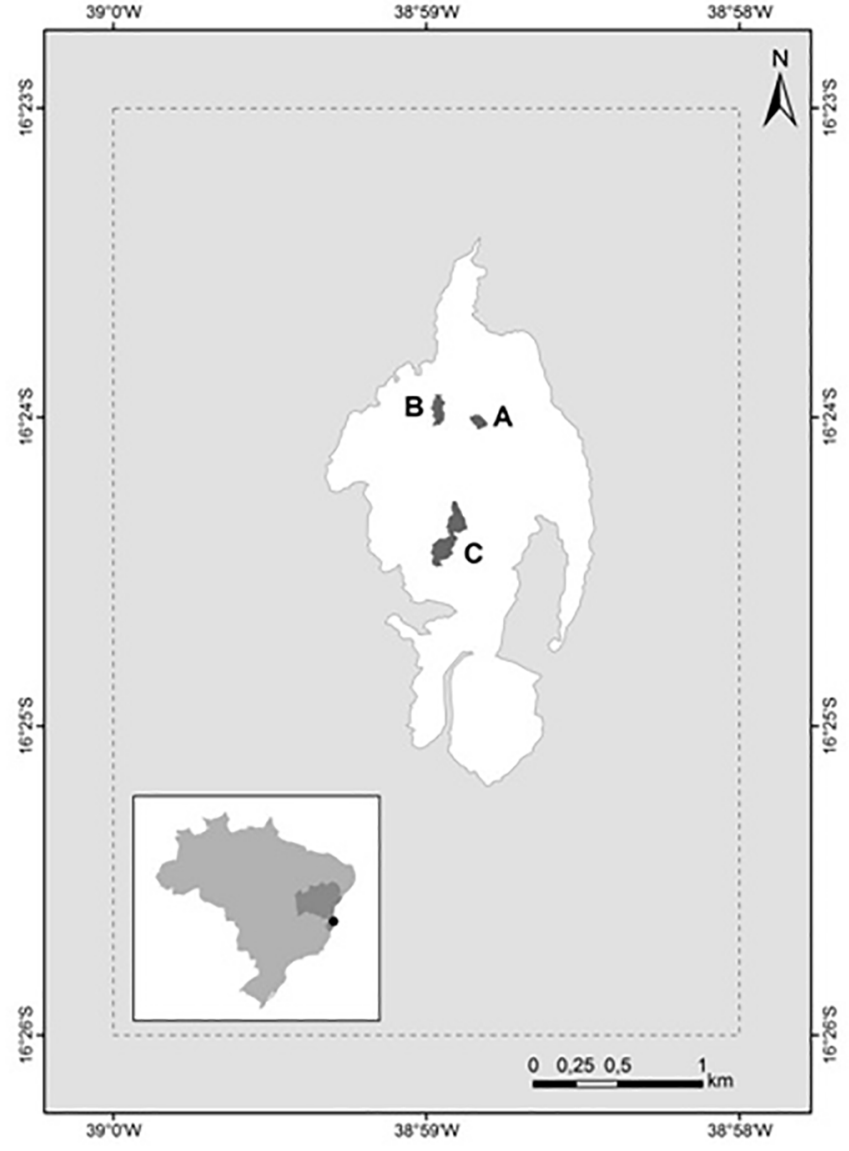

Figure 1. Location of the of Recife de Fora Marine Park (Porto Seguro, Bahia, Brazil). The letters indicate the tide pools: "A" = Dolphin pool, "B" = Visitors' pool, "C" = Panam pool, not included in this study.

(Valenciennes, 1840), which are endemic to Brazil (Floeter et al. 2008), and the endangered species Mycteroperca bonaci (Poey 1860) (Ferreira et al. 2008) and Epinephelus itajara (Lichtenstein 1822) (PadovaniFerreira et al. 2012).

Depressions in the plateau of the reef form tide pools at low tide, including the Piscina da Visitação (the visitors' pool) and Piscina do Golfinho (dolphin pool), which have historically been the park's main tourist attraction. The visitors' pool has an area of approximately 9,000 $\mathrm{m}^{2}$ and a depth of 1.4 meters. Organized visitation to this area began over three decades ago. Although the current visitor limit is 400 visitors/ day, this number peaked at 1,200 visitors/day in the past (Porto Seguro 2016). Visitation occurs at low tide, when visitors are led to the pool by park guides, when the bathers, guides and photographers feed the fish using bread, biscuits, dry fish and dog food, and shredded shrimp (Porto Seguro 2016). The dolphin pool has an area of 4,500 $\mathrm{m}^{2}$ and roughly the same depth as the visitors' pool, but has been closed to visitors since 2002. For the purposes of this study, the visitors' pool was called the "Feeding Area" (FA) and the dolphin pool "Control Area" (CA).

A manipulative experiment was conducted in each area under the following different experimental conditions: 1) "Pre-bather" comprising a period of five minutes before the bather entered the area, seeking to reproduce natural conditions without any disturbance; (2)
"Bather presence" - comprising the first five minutes after the bather entered the area, to identify changes in fish behavior in the presence of a human; (3) "Post-bather" - comprising the 5-minute period immediately after the bather left the area, to determine how the fish reacted after the end of visual stimulation and the length of time it took for them to begin stabilizing their behavior; and (4) "Feeding" - with the presence of the bather feeding the fish for a period of 5 minutes, to assess changes caused by the presence of a person offering food (Figure 2). Fish behavior and abundance under each condition was assessed using remote filming sessions.

Sampling was conducted between March and April 2014 during the daytime at low tide before the arrival of tourists. During sampling, horizontal visibility was at least 4 meters in both the FA and CA. A GoPro Hero 3 Silver Edition (GoPro Inc.) digital camera was used to record fish behavior and quantify abundance installed at a fixed point at the edge of each tidal pool and $60 \mathrm{~cm}$ from the bottom.

Recording started as soon as the camera was installed. The first 8-10 minutes of the recording were discarded to allow the fish to stabilize their behavior after the researcher left the water. The Pre-bather condition comprised the 5-minute period after stabilization. At the end of this period, the bather entered the water and remained in front of the camera at a distance of exactly 1.5 meters for 5 minutes. It is important to note that, although it is probable that the changes caused by the presence of only one bather do not fully represent those caused by the 400 bathers that visit the FA each day, the identification of significant changes in the presence of one person provides an indication of the intensity of the changes caused by a larger number of people. At the end of this period, the bather left the tidal pool and the Post-bather condition began. At the end of this period, the bather entered the pool again and remained in the same position as in the Bather presence condition, this time offering food to the reef fish for a period of 5 minutes.

The above process was repeated 4 times in each area on separate occasions. For each of the four filming sessions in each area, a one-minute frame was selected from each of the 5-minute periods, giving a total of five frames per experimental condition per session and a overall total of 20 frames per condition for each area $(n=80$ for both FA and CA). For each one-minute frame, the specific abundance of fish within a distance of 1.5 meters from the camera (distance between the camera and the bather) was quantified. Species were identified according to Humann \& Deloach (2002) and Sampaio \& Notthingham (2008).

The bather was represented by a researcher using the type of clothing and behavior used by photographers working for tour operators. The food used was the same shredded shrimp used by the tour operators, which is the most commonly used food during visitation. A total of 250 grams of food were gradually fed to the fish over the 5-minute period under the feeding conditions. This quantity corresponds to the amount fed by photographers and was based on information obtained through personal communications with the tourist agents.

To complement the experiments and to help identify possible changes in behavior, fish behavior in the two areas was recorded not only during the filming sessions, but also between experiments during normal group visits to the park, focusing on, but not limited to, the following aspects of behavior: agonistic interactions, interaction with the bather, attacks on the bather, reaction time to in-water food stimulation, and opportunistic feeding (for example, herbivores feeding on shrimp). 


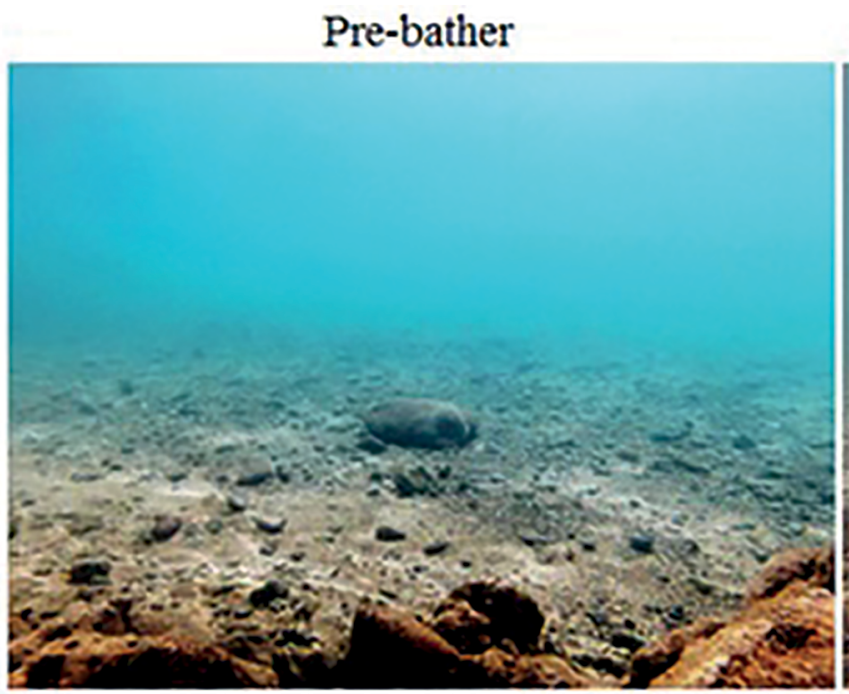

Post-bather

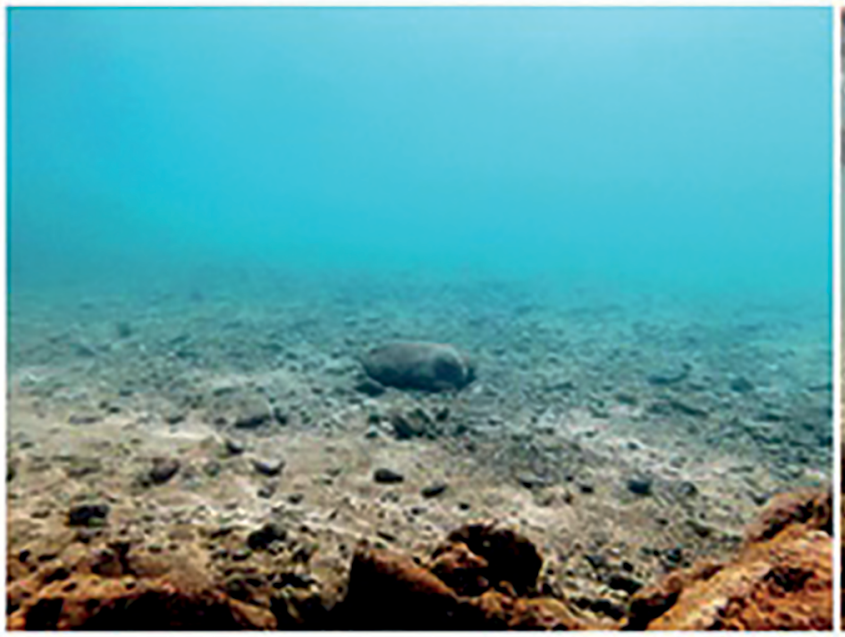

Figure 2. Experimental conditions in the Recife de Fora Marine Park.

\section{Statistical analysis}

A two-way nested ANOVA was used to compare fish abundance between different experimental conditions in both areas, followed by Tukey's post hoc test when a statistically significant result was obtained. Abundance data was $\log (\mathrm{x}+1)$ transformed to meet ANOVA assumptions. The analyses were performed using the software package Statistica 8.0 (StatSoft 2007), adopting a 5\% significance level.

\section{Results}

A total of 2,816 individuals comprising nine families and 17 species were identified from the 160 frames, which is equivalent to $32.6 \%$ of the 43 species registered in the RFMP. Fourteen of these species consumed food in the CA, compared to only four in the FA (Table 1).

The most abundant species under all conditions in the Feeding Area and Control Area were Abudefduf saxatilis and Haemulon aurolineatum, respectively (Figure 3).

\section{Presence of bather}

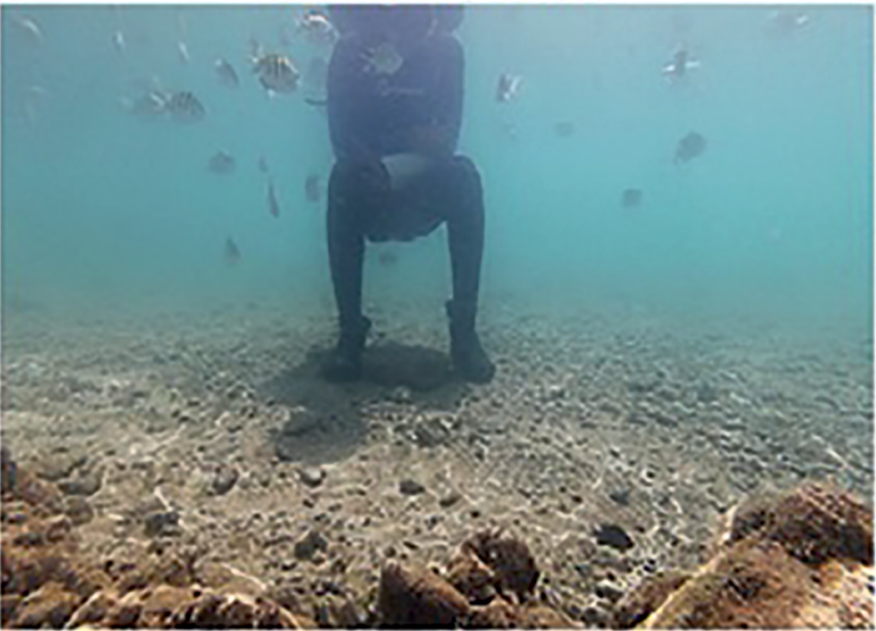

Feeding

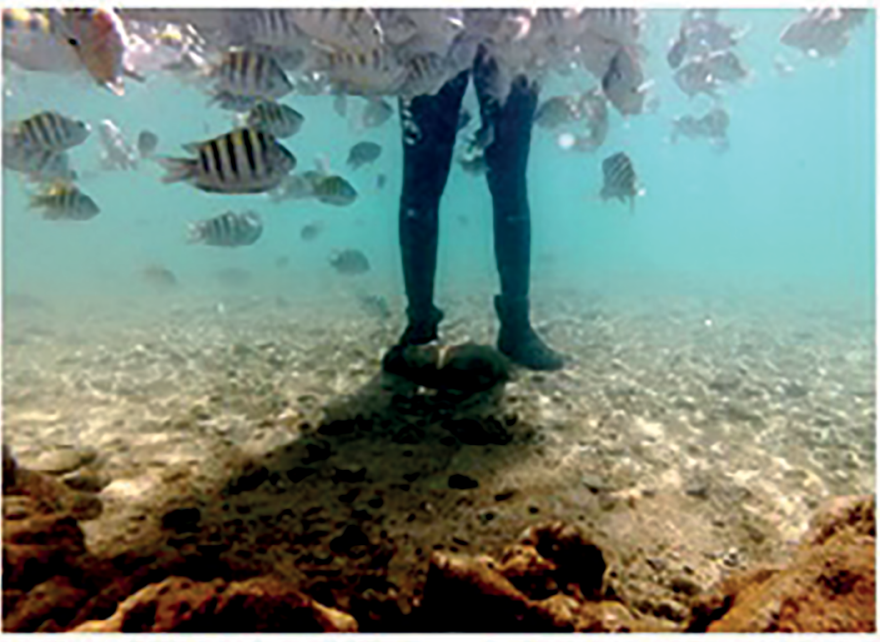

In the FA, the abundance of $A$. saxatilis differed significantly between different experimental conditions $(\mathrm{F}=80.89$, df $=3, \mathrm{p}$ $<0.05)$ and areas $(F=76.62, \mathrm{df}=1, \mathrm{p}<0,05)$. Species abundance was significantly greater under feeding conditions in both the FA and CA. The density of $A$. saxatilis was significantly greater in the presence of the bather than in the absence of a bather in the FA. Densities did not differ significantly between the other conditions (Figure 4, Table 2).

The abundance of $A$. saxatilis in the FA was shown to significantly greater under experimental conditions involving human presence (Figure 4, Table 2). Abundance in the FA was over twice that in the CA in presence of feeding.

Opportunistic behavior was observed in herbivorous species such as Stegastes fuscus, Scarus trispinosus, Sparisoma axillare, Acanthurus chirurgus, A. coeruleus, and A. bahianus, which consumed shrimp. In the FA, in the presence of a bather (without feeding) and in the presence of feeding, large numbers of $A$. saxatilis approached the bather, migrating from different areas of the pool to the experiment site. In contrast, in the CA, besides not attracting this species, the presence of the bather scared away other species. 
Table 1. Fish species registered under feeding conditions in the Feeding Area and Control Area. Recife de Fora Marine Park, Bahia, Brazil. "Consumed" indicates species that consumed the food provided.

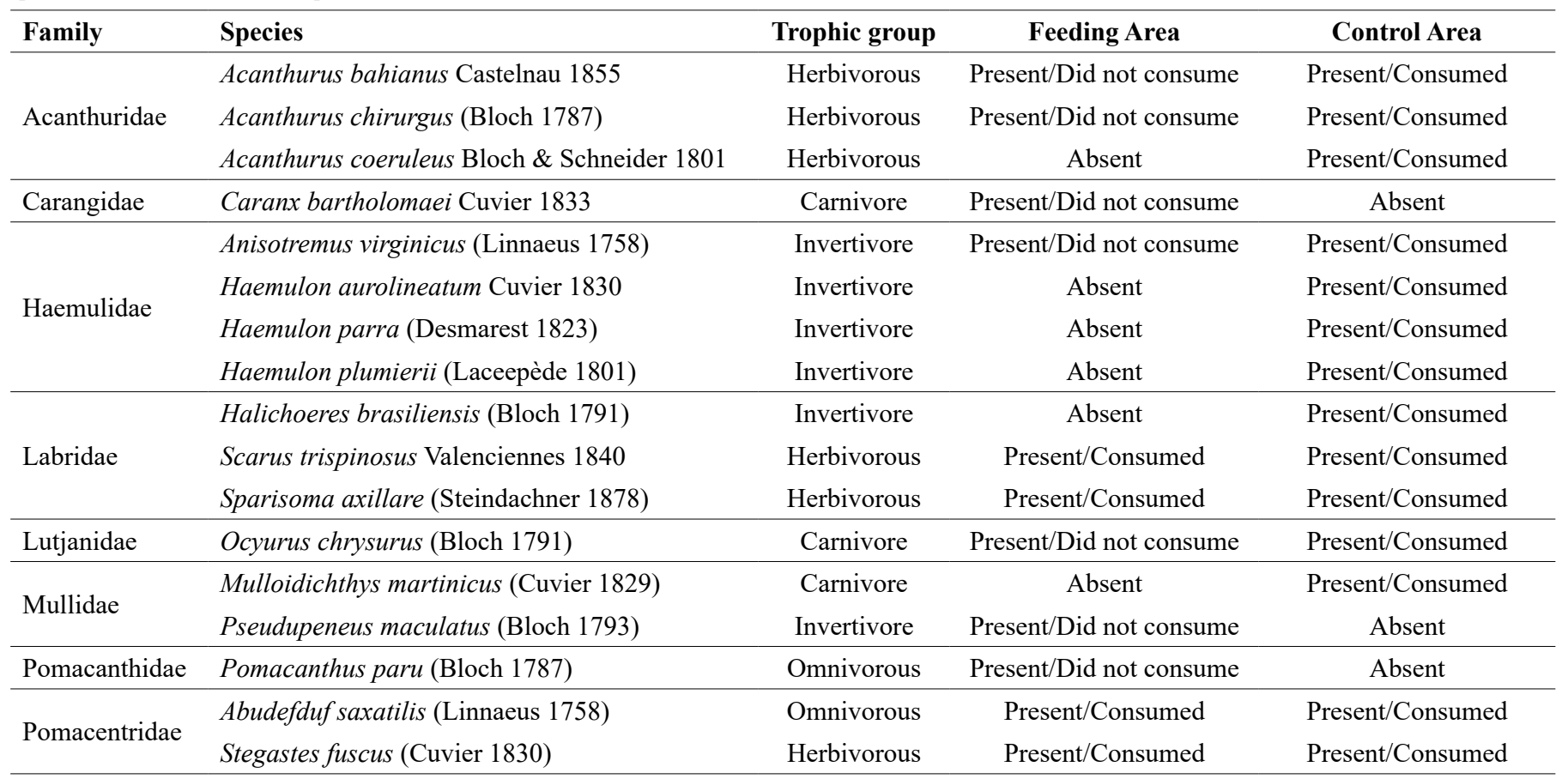

Aggressive behavior was observed in A. saxatilis during feeding in the FA, consisting of agonistic interactions (biting and chasing other fish) with conspecific individuals and other species, such as Stegastes fuscus, Acanthurus chirurgus, and Scarus trispinosus. A. saxatilis also directed attacks at the bather, biting his hands during feeding. This type of aggressive behavior did not occur in the CA.

The grouping of $A$. saxatilis promoted by feeding in the FA may lead to "thefts" from $S$. fuscus' algae farms. It is possible that the abundance of $A$. saxatilis leads to increased agonistic behavior from individuals of the species $S$. fuscus, which leave their algae farms unprotected when they chase intruders. In such situations, conspecific individuals and other species, such as A. saxatilis, Acanthurus bahianus, and A. chirurgus, feed on the cultivated algae. In some cases, individuals of the territorial species $S$. fuscus stopped defending their territories to consume the food provided by the bather, thus enabling other fish to "steal" from their farms.

\section{Discussion}

The number of species observed consuming food shows that fish feeding directly affects one third of the species of reef fish found in the RFMP. In a study conducted in MPAs in the southeast of Kenya, the number of species that consumed bread fed by tourists ( 14 species) was identical to that found by the present study (Hémery \& McClanahan 2005). The fish identified by this study also included individuals from the families Pomacentridae, Acanthuridae and Labridae, suggesting that fish feeding can affect ichthyofauna in different geographic regions in similar ways. However, the lack of experimental studies does not allow comparisons to be made with other regions.

The low species richness among individuals that consumed food provided by the bather in the FA is probably due to the high abundance and aggressive nature of $A$. saxatilis in this area. It is also interesting to note that four of the species that consumed food in the CA did not consume food in the FA, despite being present in both areas. This finding corroborates the findings of other studies that suggest aggressive species tend to benefit more from fish feeding by excluding nonaggressive species (Perrine 1989, Orams 2002).

The results also suggest that feeding promoted an increase in the abundance of $A$. saxatilis in the FA. Although studies conducted prior to the introduction of tourism to this tidal pool do not exist, this hypothesis is supported by the behavioral changes observed in this study and by the findings of other studies (Medeiros et al. 2007, Ilarri et al. 2008, Feitosa et al. 2012). A. saxatilis is an abundant species in tropical reefs in the Atlantic Ocean (Humann \& Deloach 2002) and is considered to be a generalist and opportunistic due to its omnivorous diet (Deloach 1999). A. saxatilis has also been reported to be the most abundant species in feeding areas in other reefs in the northeast of Brazil, including Picãozinho (Medeiros et al. 2007, Ilarri et al. 2008) and Maragogi (Feitosa et al. 2012), where feeding was pointed out by the authors to be the primary cause of the increased abundance of this species. Two species of the genus Abudefduf (A. sexfasciatus and $A$. sparoides) were also found to be the most abundant species in feeding areas in the Malindi, Watamu, and Mombasa MPAs in southeastern Kenya (Hémery \& McClanahan 2007).

Our findings indicate that the intensification of fish feeding activities in MPAs can lead to an increase in the size of populations of Abudefduf and other generalist fish species, leading to a corresponding increase in the number of omnivores in areas where feeding activity is frequent. It is known that fish feeding is associated with higher fish survival and reproduction rates (Sweatman 1996), favoring an increase in the size of populations of fish that consume the food provided during feeding. However, the impact of these increases in population size on the structure of reef communities remains unclear. Therefore, monitoring these fish populations is essential to ensuring the effective management of MPAs. 
6

Biota Neotrop., 18(3): e20170339, 2018

Paula, Y.C. et al.

Feeding Area

Pre-Bather

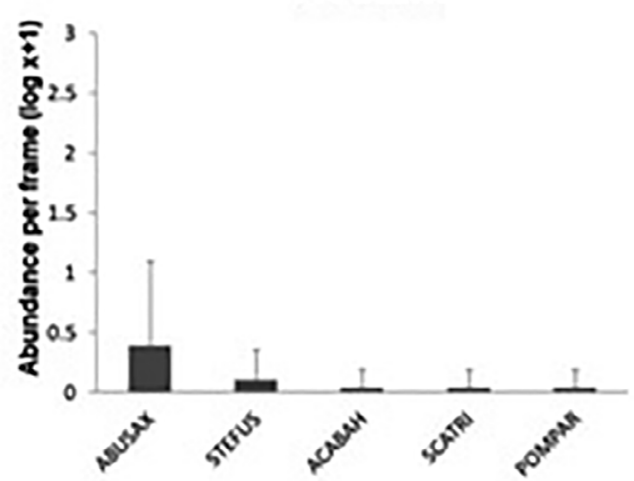

Presence of bather
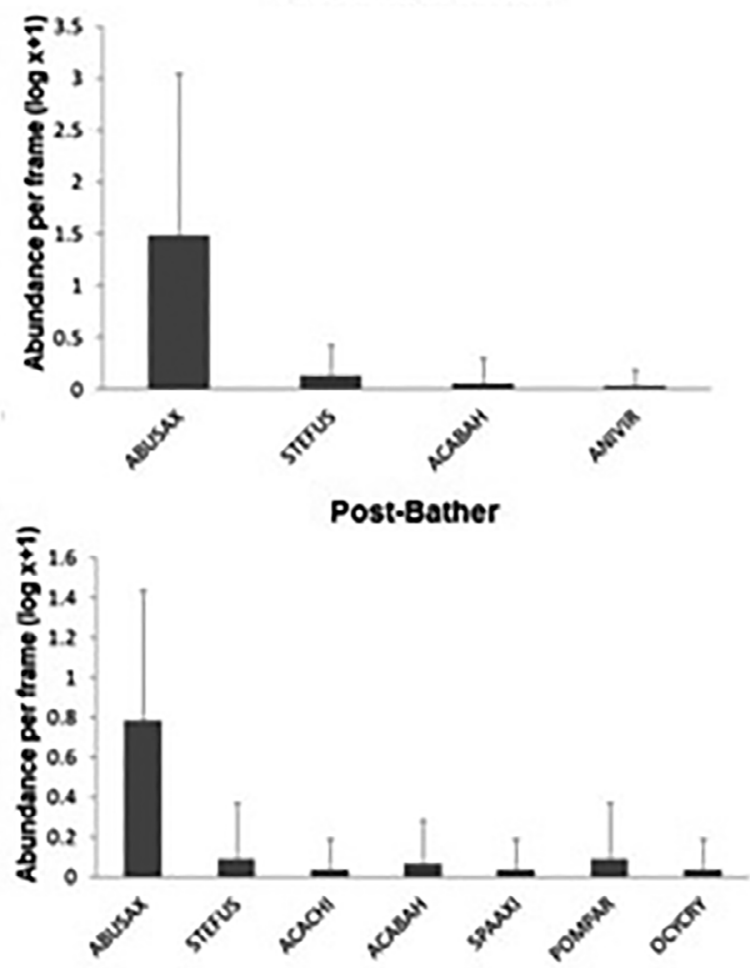

Feeding

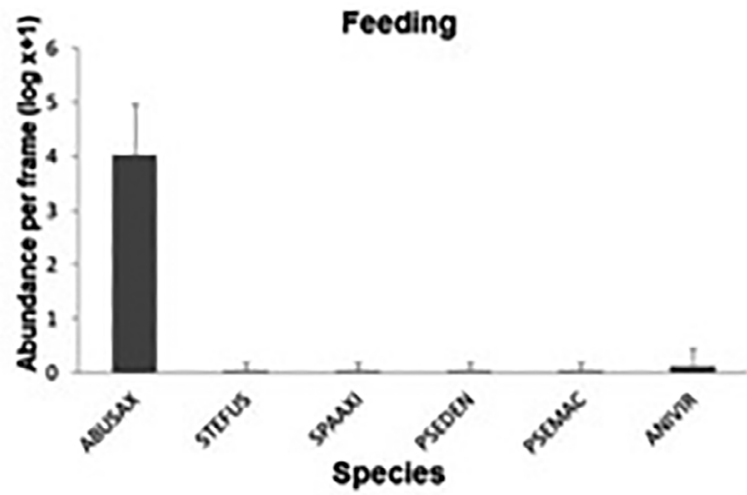

Control Area

Pre-Bather

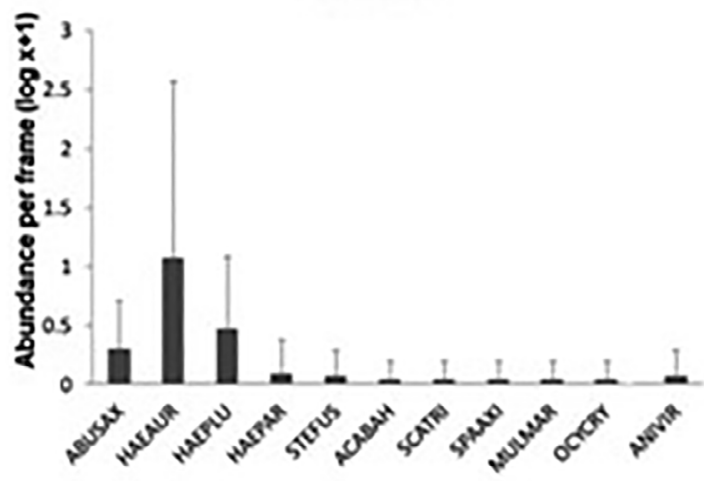

Presence of bather

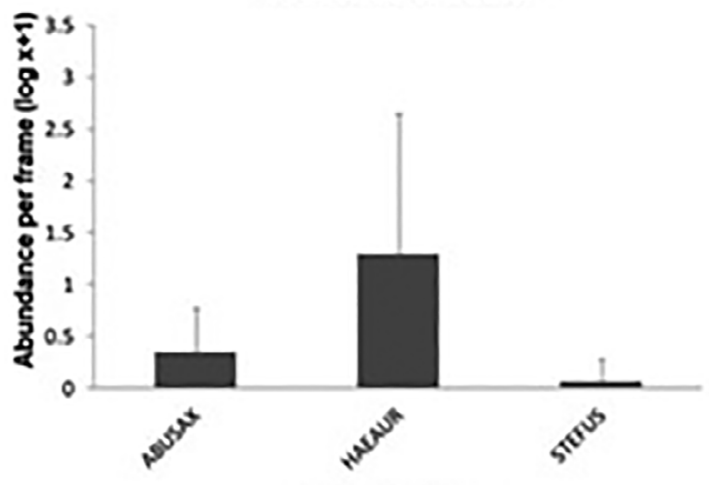

Post-Bather
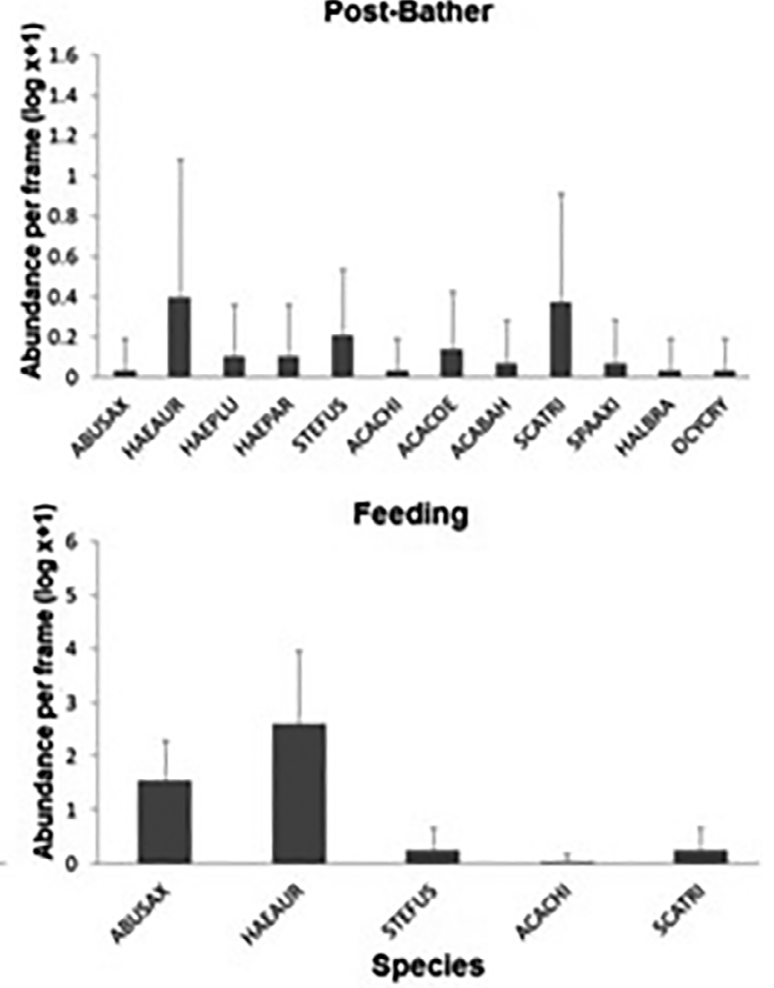

Figure 3. Average Abundance $( \pm \mathrm{SD})$ of fish species under the four experimental conditions in the Feeding and Control Areas in the of Recife de Fora Marine Park. Data $\log (\mathrm{x}+1)$ transformed. $\mathrm{ABUSAX}=$ Abudefduf saxatilis, $\mathrm{ACABAH}=$ Acanthurus bahianus, $\mathrm{ACACHI}=$ A. chirurgus, $\mathrm{ACACOE}=$ A. coeruleus, $\mathrm{ANIVIR}=$ Anisotremus virginicus, $\mathrm{HAEAUR}=$ Haemulon aurolineatum, $\mathrm{HAEPAR}=$ H. parra, $\mathrm{HAEPLU}=$ H. plumieri, HALBRA $=$ Halichoeres brasiliensis, MULMAR $=$ Mulloidichthys martinicus, OCYCRY $=$ Ocyurus chrysurus, POMPAR = Pomacanthus paru, $\mathrm{PSEMAC}=$ Pseudupeneus maculatus, $\mathrm{SCATRI}=$ Scarus trispinosus, $\mathrm{SPAAXI}=$ Sparisoma axillare, $\mathrm{STEFUS}=$ Stegastes fuscus.

http://www.scielo.br/bn

http://dx.doi.org/10.1590/1676-0611-BN-2017-0339 


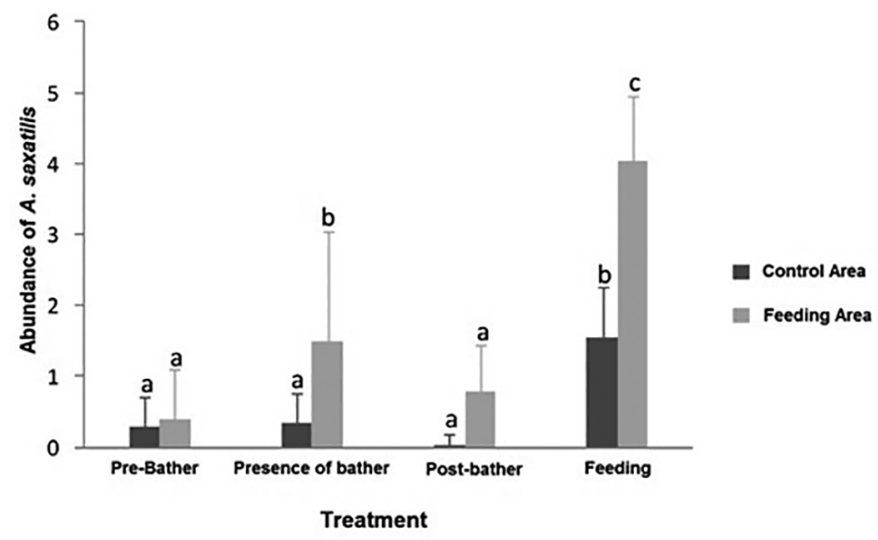

Figure 4. Average abundance of Abudefduf saxatilis ( \pm SD) under different experimental conditions in the Feeding and Control Areas of Recife de Fora Marine Park. Different letters indicate a significant difference between treatments according to the results of the Tukey post hoc test.

Our results support the theory proposed by other authors that suggests that fish feeding is the leading cause of the increased abundance of omnivores associated with increases in the size of the population of A. saxatilis (Medeiros et al. 2007, Ilarri et al. 2008, Feitosa et al. 2012). The results of this study should therefore be used to inform tourism management planning in the RFMP and in other MPAs where fish feeding is permitted.

The behavioral findings of this study suggest that fish feeding also causes changes in the natural behavior of certain species. A. saxatilis showed a change in behavior in the FA, approaching the bather even in the absence of feeding. This suggests a change in behavior conditioned by human presence (visual stimulus) and the presence of food (chemical stimulus). According to Bond (1979), behavioral changes can be caused by both visual and olfactory stimuli and may lead to differences in fish distribution patterns. The behavior of $A$. saxatilis towards people has been studied in feeding areas in reefs in the states of Paraiba (Medeiros et al. 2007, Ilarri et al. 2008, Feitosa et al. 2012) and Pernambuco (Feitosa et al., 2012) in the Northeast Region of Brazil. Furthermore, A. sexfasciatus showed the same pattern of habituation to the presence of humans in feeding areas in MPAs in Kenya (Hémery \& McClanahan 2007). The conditioning of $A$. saxatilis may be explained by the learning ability of fish, as reported by Shettleworth (1984). In extreme cases, conditioning of the behavior of fish to the presence of humans can lead to dependence on fish feeding (Harriot 2002).
We also observed aggressiveness among individuals of the species A. saxatilis in the FA, evident in frequent agonistic interactions in competition for food. It is believed that fish feeding may cause increased aggression and changes in the genetic structure of populations due to the possible natural selection of more aggressive fish (Moribe 2000, Semeniuk \& Rothley 2008, Hammerschlag et al. 2012). Furthermore, biting during agonistic interactions may cause skin lesions, making the injured fish more susceptible to infections (Brookhouse et al. 2013).

Changes in fish behavior due to intense fish feeding activities have been reported by other studies. At the Shark Reef Marine Reserve in Fiji, fish feeding has been shown to cause shifts in the movement patterns of the bull shark (Carcharhinus leucas), which attended the feeding area with increasing frequency over time, leading to changes in habitat loyalty (Brunnschweiler \& Barnett 2013). In the Cayman Islands, daytime fish feeding activities led to a reversal of the feeding patterns of the naturally nocturnal southern stingray (Hypanus americanus) and affected their spatial distribution, leading to unnatural grouping (Corcoran et al. 2013). Thus, our findings are consistent with the behavioral changes observed in other studies conducted with other species in other regions around the world.

Our findings also show that species that are endemic to Brazil, such as $S$. trispinosus, S. axillare, H. brasiliensis, and S. fuscus, consumed the food provided. Besides being endemic, $S$. trispinosus is an endangered species from the family Labridae found in the South Atlantic (PadovaniFerreira et al. 2012) and is considered extinct in other parts of Brazil, such as Arraial do Cabo in the State of Rio de Janeiro (Floeter et al. 2007). Labridae also plays an important role in controlling macroalgae populations in reef environments (Francini-Filho \& de Moura 2008, Bonaldo et al., 2014) and thus affects the balance between coral reefs and macroalgae, which is highly important to the maintenance of healthy coral reefs (Ainsworth \& Mumby 2015). Given the conservation status and role played by this family of fish, PMA management and conservation strategies should take into consideration the possible effects of fish feeding on the biology of these fish.

The change in the feeding behavior of the herbivores $S$. fuscus, $S c$. trispinosus, S. axillare, A. chirurgus, A. coeruleus and A. bahianus, indicates that fish feeding may cause changes in food preferences. Herbivorous fish are essential for maintaining the resilience of reef environments (Bellwood et al. 2004, Mumby et al. 2006). Therefore, considering the importance of the ecosystem services provided by these herbivores, further research should be conducted into the effects of fish feeding on the food preferences of these species.

Table 2. Tukey's post hoc test results for Abudefduf saxatilis showing the association between abundance and the factors experimental condition and area. Recife de Fora Marine Park, Bahia, Brazil.

\begin{tabular}{|c|c|c|c|c|c|c|c|c|c|}
\hline & Area & Treatment & 1 & 2 & 3 & 4 & 5 & 6 & 7 \\
\hline 1 & FA & Pre-Bather & & & & & & & \\
\hline 2 & FA & Bather presence & $<0,05$ & & & & & & \\
\hline 4 & FA & Feeding & $<0,05$ & $<0,05$ & $<0,05$ & & & & \\
\hline 5 & $\mathrm{CA}$ & Pre-Bather & NS & $<0,05$ & NS & $<0,05$ & & & \\
\hline 7 & $\mathrm{CA}$ & Pos-Bather & NS & $<0,05$ & NS & $<0,05$ & NS & NS & \\
\hline 8 & $\mathrm{CA}$ & Feeding & $<0,05$ & NS & $<0,05$ & $<0,05$ & $<0,05$ & $<0,05$ & $<0,05$ \\
\hline
\end{tabular}

$\mathrm{FA}=$ Feeding Area; $\mathrm{CA}=$ Control Area; NS = not statistically significant 
Fish feeding in RFMP may also be affecting the health of these animals by increasing fat deposition around vital organs (Moribe 2000, Orams 2002), susceptibility to microbial infections, stomach ulcers and ectodermal parasites, and skin lesions (Brookhouse et al. 2013; Semeniuk \& Rothley 2008). Furthermore, the grouping of animals caused by fish feeding may favor the spread of diseases among conspecific individuals and other species (Orams 2002). These and other effects of fish feeding on fish health should be taken into account to ensure the effective management of MPAs.

Our findings suggest that changes have occurred to the population of A. saxatilis, which are likely to resonate throughout the entire structure of the ichthyofauna. The present study highlights behavioral changes among reef fish resulting from fish feeding activities in the RFMP. These changes include habituation to human presence, conditioning to fish feeding, increased aggressiveness, attacks on humans, and shortterm changes in species distribution. To prevent the intensification of changes caused by fish feeding, the competent authorities should take appropriate steps to control the quantity and frequency of feeding and monitor the dynamics of affected fish populations.

\section{Acknowledgements}

The research presented in this study was carried out with financial aid of Projeto Coral Vivo, sponsored by Petrobras (by Programa Petrobras Socioambiental), Arraiald'Ajuda Eco Parque, and by Brazilian Federal Agency for Support and Evaluation of Graduate Educations (CAPES) - Research Announcement Ciências do Mar II. This work was conducted during a fellowship to E. N. Calderon, supported by Brazilian Federal Agency for Support and Evaluation of Graduate Educations (CAPES), an graduate fellowship to Y. C. de Paula from Fundação de Amparo ao Pesquisador do Estado da Bahia (FAPESB), and fellowship to A. Schiavetti from Conselho Nacional de Desenvolvimento Científico e Tecnológico (CNPq). We are thankful The collection permit was granted by the Recife de Fora Marine Park, Porto Seguro, Bahia, Brazil.

\section{Author Contributions}

Yuri Cruz de Paula: substantial contribution in the concept and design of the study; contribution to data collection; contribution to data analysis and interpretation; contribution to manuscript preparation; contribution to critical revision, adding intelectual content;

Alexandre Schiavetti: substantial contribution in the concept and design of the study; contribution to data analysis and interpretation; contribution to manuscript preparation; contribution to critical revision, adding intelectual content.

Cláudio L. S. Sampaio: contribution to manuscript preparation; contribution to critical revision, adding intelectual content.

Emiliano Calderon: substantial contribution in the concept and design of the study; contribution to data collection; contribution to data analysis and interpretation; contribution to manuscript preparation; contribution to critical revision, adding intelectual content.

\section{Conflicts of interest}

The authors declare that they have no conflict of interest related to the publication of this manuscript.

\section{References}

AINSWORTH, C. H. \& MUMBY, P. 2015. Coral-algal phase shifts alter fish communities and reduce fisheries production. Global Change Biology 21: $165-172$.

ALBUQUERQUE, T., LOIOLA, M., NUNES, J. A. C. C., REIS-FILHO, J. A., SAMPAIO, C. L. S. \& LEDUC, A. O. H. C. 2014. In situ effects of human disturbances on coral reef-fish assemblage structure: temporary and persisting changes are reflected as a result of intensive tourism. Marine and Freshwater Research 66: 23-32.

BEEDEN, R., MAYNARD, J., JOHNSON, J., DRYDEN, J., KININMONTH, S. \& MARSHALL, P. 2014. No-anchoring areas reduce coral damage in an effort to build resilience in Keppel Bay, southern Great Barrier Reef. Australasian Journal of Environmental Management 21: 311-319.

BELlWOOD, D. R., HUGHES, T. P., FOLKE, C. \& NYSTRÖM, M. 2004. Confronting the coral reef crisis. Nature 429: 827-833.

BONALDO, R., HOEY, A. S. \& BELLWOOD, D. R. 2014. The ecossystem roles of Parrotfishes on tropical reefs. Oceanography and Marine Biology: An Annual Review, 2014, 52, 81-132.

BOND, C. E. 1979. Biology of fishes. WB Sounders Company, Sounders.

BRANDER, L. M., VAN BEUKERING, P. V. \& CESAR, H. S. J. 2007. The recreational value of coral reefs: a meta-analysis. Ecological Economics 63: 209-218.

BROOKHOUSE, N., BUCHER, D. J., ROSE, K., KERR, I. \& GUDGE, S. 2013. Impacts, risks and management of fish feeding at Neds Beach, Lord Howe Island Marine Park, Australia: a case study of how a seemingly innocuous activity can become a serious problem. Journal of Ecotourism 12: 165-181.

BRUNNSCHWEILER, J.M. \& BARNETT, A. 2013. Opportunistic Visitors: Long-Term Behavioural Response of Bull Sharks to Food Provisioning in Fiji. PLoSONE 8: e58522.

BRUNNSCHWEILER, J. M., ABRANTES, K. G. \& BARNETT, A. 2014. Long-Term Changes in Species Composition and Relative Abundances of Sharks at a Provisioning Site. PLoSONE 9: e86682.

CASTRO, C.B. \& PIRES, D.O. 2001. Brazilian coral reefs: What we already know and what is still missing. Bulletin of Marine Science 69: 357-371.

CHAVES, L. D. C., NUNES, J. D. A. C. \& SAMPAIO, C. L. 2010. Shallow reef fish communities of South Bahia coast, Brazil. Brazilian Journal of Oceanography 58: 33-46.

CORCORAN, M. J., WETHERBEE, B. M., SHIVJI, M. S., POTENSKI, M. D. \& CHAPMAN, D. D.. 2013. Supplemental Feeding for Ecotourism Reverses Diel Activity and Alters Movement Patterns and Spatial Distribution of the Southern Stingray, Dasyatis americana. PLoSONE 8: e59235.

COMEAU, S., CARPENTER, R. C., LANTZ, C. A. \& EDMUNDS, P. J. 2015. Ocean acidification accelerates dissolution of experimental coral reef communities. Biogeosciences 12: 365-372.

COSTA JR., O. S., ATTRILL, M. J., PEDRINI, A. G. \& DE-PAULA, J. C. 2002. Spatial and seasonal distribution of seaweeds on coral reefs from Southern Bahia, Brazil. Botanica Marina 45: 346-355.

CREED, J. C. \& AMADO FILHO, G. M. 1999. Disturbance and recovery of the macroflora of a seagrass (Halodule wrightii Ascherson) meadow in the Abrolhos Marine National Park, Brazil: an experimental evaluation of anchor damage. Journal of experimental marine biology and ecology 235: 285-306.

DELOACH, N. 1999. Reef fish behavior: Florida, Caribbean, Bahamas. New World Publications, Jacksonville.

ECKRICH, C. E. \& HOLMQUIST, J. G. 2000. Trampling in a seagrass assemblage: direct effects, response of associated fauna, and the role of substrate characteristics. Marine Ecology. Progress series 201: 199-209.

FEITOSA, C. V., CHAVES, L. D. C. T., FERREIRA, B. P. \& DE ARAUJO, M. E. 2012. Recreational fish feeding inside Brazilian MPAs: impacts on reef fish community structure. Journal of the Marine Biological Association of the United Kingdom 92: 1525-1533.

FERREIRA, B.P., ROCHA, L., GASPAR, A.L.B., SADOVY, Y. \& CRAIG, M. 2008. Mycteroperca bonaci. The IUCN Red List of Threatened Species 2008: http://dx.doi.org/10.2305/IUCN.UK.2008.RLTS.T132724A3433339. (Last access in 17 January 2018). 
FLOETER, S. R., KROHLING, W., GASPARINI, J. L., FERREIRA, C. E. \& ZALMON, I. R. 2007. Reef fish community structure on coastal islands of the southeastern Brazil: the influence of exposure and benthic cover. Environmental Biology of Fishes 78: 147-160.

FLOETER, S. R., ROCHA, L. A., ROBERTSON, D. R., JOYEUX, J. C., SMITH-VANIZ, W. F., WIRTZ, P., EDWARDS, A. J., BARREIROS, J. P., FERREIRA, C. E. L., GASPARINI, J. L., BRITO, A., FALCO'N, J. M., BOWEN, B. W. \& BERNARDI, G. 2008. Atlantic reef fish biogeography and evolution. Journal of Biogeography 35: 22-47.

FRANCINI-FILHO, R. B. \& DE MOURA, R. L. 2008. Dynamics of fish assemblages on coral reefs subjected to different management regimes in the Abrolhos Bank, eastern Brazil. Aquatic Conservation: Marine and Freshwater Ecosystems 18: 1166-1179.

GIGLIO, V. J., LUIZ, O. J. \& SCHIAVETTI, A. 2016. Recreational Diver Behavior and Contacts with Benthic Organisms in the Abrolhos National Marine Park, Brazil. Environmental management 57: 637-648.

GIGLIO, V. J., LUIZ, O. J. \& SCHIAVETTI, A. 2015. Marine life preferences and perceptions among recreational divers in Brazilian coral reefs. Tourism Management 51: 49-57.

GIGLIO, V. J., TERNES, M. L. F., MENDES, T. C., CORDEIRO, C. A.M. M. \& FERREIRA, C. E. L. 2017. Anchoring damages to benthic organisms in a subtropical scuba dive hotspot. J. Coast. Conserv., 21 (2017), pp. 311-316.

GREAT BARRIER REEF MARINE PARK AUTHORITY. 2000. Whale and dolphin conservation in the Great Barrier Reef Marine Park, Policy Document. Great Barrier Reef Marine Park Authority, Townsville, Queensland. http://www. gbrmpa.gov.au/corp_site/info_services/publicatio ns/whale_dolphin/index.html (Last access in 5 April 2017).

GREEN, E. \& DONNELLY, R. 2003. Recreational scuba diving in Caribbean marine protected areas: Do the users pay?. AMBIO: A Journal of the Human Environment 32: 140-144.

HAMMERSCHLAG, N., GALLAGHER, A. J., WESTER, J., LUO, J. \& AULT, J. S. 2012. Don't bite the hand that feeds: assessing ecological impacts of provisioning ecotourism on an apex marine predator. Functional Ecology 26: $567-576$

HARRIOTT, V. J. 2002. Marine tourism impacts and their management on the Great Barrier Reef. Cooperative Research Centre Reef Research Centre, Townsville.

HEIN, M. Y., LAMB, J. B., SCOTT, C. \& WILLIS, B. L. 2015. Assessing baseline levels of coral health in a newly established marine protected area in a global scuba diving hotspot. Marine Environmental Research 103: 56-65.

HÉMERY, G. \& MCCLANAHAN, T. R. 2007. Effect of recreational fish feeding on reef fish community composition and behaviour. Western Indian Ocean Journal of Marine Science 4: 123-134.

HUMMAN, P. \& DELOACH, N. 2002. Reef fish identification: Florida, Caribbean and Bahamas. 2 ed. New World Publication Inc, Jacksonville.

ILARRI, M. D. I., SOUZA, A. T. D., MEDEIROS, P. R. D., GREMPEL, R. G. \& ROSA, I. M. D. L. 2008. Effects of tourist visitation and supplementary feeding on fish assemblage composition on a tropical reef in the Southwestern Atlantic.Neotropical Ichthyology 6: 651-656.

KININMONTH, S., LEMM, S., MALONE, C. \& HATLEY, T. 2014. Spatial vulnerability assessment of anchor damage within the Great Barrier Reef World Heritage Area, Australia. Ocean \& Coastal Management 100: 20-31.

LAMB, J. B., TRUE, J. D., Piromvaragorn, S. \& Willis, B. L. 2014. Scuba diving damage and intensity of tourist activities increases coral disease prevalence. Biological Conservation 178: 88-96.

MCCLANAHAN, T. R., GRAHAM, N. A. J., MACNEIL, M. A. \& CINNER, J. E. 2015. Biomass based targets and the management of multispecies coral reef fisheries. Conservation Biology 29: 409-417.

MEDEIROS, P. R., GREMPEL, R. G., SOUZA, A. T., ILARRI, M. I. \& SAMPAIO, C. L. S. 2007. Effects of recreational activities on the fish assemblage structure in a northeastern Brazilian reef. Pan-American Journal of Aquatic Sciences 2: 288-300.

MILAZZO, M. 2011. Evaluation of a behavioural response of Mediterranean coastal fishes to novel recreational feeding situation. Environmental Biology of Fishes 91: 127-132.
MILAZZO, M., CHEMELLO, R., BADALAMENTI, F., CAMARDA, R. \& RIGGIO, S. 2002. The impact of human recreational activities in marine protected areas: what lessons should be learnt in the Mediterranean sea? Marine ecology 23: 280-290.

MILAZZO, M. A. R. C. O., BADALAMENTI, F., FERNÁNDEZ, T. V. \& CHEMELLO, R. 2005. Effects of fish feeding by snorkellers on the density and size distribution of fishes in a Mediterranean marine protected area. Marine Biology 146: 1213-1222.

MORIBE, J. T. 2000. Visitor attitudes toward the prohibition of fish feeding in the Hanauma Bay Marine Life Conservation District. Master thesis, The University of Washington, Seattle.

MUMBY, P. J. \& ANTHONY, K. 2015. Resilience metrics to inform ecosystem management under global change with application to coral reefs. Methods in Ecology and Evolution 6: 1088-1096.

MUMBY, P. J., DAHLGREN, C. P., HARBORNE, A. R., KAPPEL, C. V., MICHELI, F., BRUMBAUGH, D. R. \& GILL, A. B. 2006. Fishing, trophic cascades, and the process of grazing on coral reefs. Science 311: 98-101.

ORAMS, M. B. 2002. Feeding wildlife as a tourism attraction: a review of issues and impacts. Tourism management 23: 281-293.

PADOVANI-FERREIRA, B., FLOETER, S., ROCHA, L.A., FERREIRA, C.E., FRANCINI-FILHO, R., MOURA, R., GASPAR, A.L. \& FEITOSA, C. 2012 Scarus trispinosus. In: IUCN 2016. IUCN Red List of Threatened Species. http://www.iucnredlist.org (Last access in 5 April 2016).

PEREIRA, P. H. C., MORAES, R. L., DOS SANTOS, M. V. B., LIPPI, D. L., FEITOSA, J. L. L. \& PEDROSA, M. 2014. The influence of multiple factors upon reef fish abundance and species richness in a tropical coral complex. Ichthyological Research 61: 375-384.

PERRINE, D. 1989. Reef fish feedings: amusement or nuisance. Sea Frontiers 35: $272-279$.

PORTO SEGURO. 2016. Plano de Manejo Parque Natural do Recife de Fora. Floram Engenharia e Meio Ambiente, Porto Seguro.

SAMPAIO, C.L.S. \& M.C. NOTTINGHAM. 2008. Guia para identificação de peixes ornamentais. Volume I: Espécies Marinhas. Brasília. Edições IBAMA, 205 pp.

SAPHIER, A.D. \& HOFFMANN, T.C. 2005. Forecasting models to quantify three anthropogenic stresses on coral reefs from marine recreation: anchor damage, diver contact and copper emission from antifouling paint. Marine Pollution Bulletin 51: 590-598.

SARMENTO, V. C. \& SANTOS, P. J. P. 2012. Trampling on coral reefs: tourism effects on harpacticoid copepods. Coral Reef 31: 135-146.

SEMENIUK, C.A.D. \& ROTHLEY, K.D. 2008. Costs of group-living for a normally solitary forager: effects of provisioning tourism on southern stingrays Dasyatis americana. Marine Ecology-Progress Series 357: 271-282.

SHETTLEWORTH, S.J. 1984. Learning and behavioral ecology.In Behavioural Ecology (J.R. Krebs \& N.B. Davies, eds.). Blackwell Scientific, Oxford, p. $170-194$.

STATSOFT. INC. 2007.STATISTICA (data analysis software system). http:// www.statsoft.com (Last access in 11 March 2015).

SWEATMAN, H. 1996. Impact of tourist pontoons on fish assemblages on the Great Barrier Reef. Tech. Rep. Cooperative Research Centre Reef Research Center 5: 54.

WEAR, S. L. \& THURBER, R. V. 2015. Sewage pollution: mitigation is key for coral reef stewardship. Annals of the New York Academy of Sciences 1355: $15-30$.

WILLIAMSON, J. E., BYRNES, E. E., CLARK, J. A., CONNOLLY, D. M., SCHILLER, S. E., THOMPSON, J. A. \& RAOULT, V. 2017. Ecological impacts and management implications of reef walking on a tropical reef flat community. Marine Pollution Bulletin 114: 742-750. 